\title{
The acceptance of covid-19 vaccines in Sub-Saharan Africa: Evidence from 6 national phone surveys
}

\author{
Shelton Kanyanda ${ }^{1}$, Yannick Markhof ${ }^{2}$, Philip Wollburg ${ }^{3}$, Alberto Zezza ${ }^{4 *}$ \\ ${ }^{1}$ Consultant, World Bank, Development Data Group \\ ${ }^{2}$ Consultant, World Bank, Development Data Group \\ ${ }^{3}$ Economist, World Bank, Development Data Group \\ ${ }^{4}$ Program Manager, World Bank, Development Data Group \\ * corresponding author \\ azezza@worldbank.org
}

Word count: 3,921

\section{Abstract \\ Introduction}

Recent debates surrounding the lagging covid-19 vaccination campaigns in low-income countries center around vaccine supply and financing. Yet, relatively little is known about attitudes towards covid-19 vaccines in these countries and in Africa in particular. In this paper, we provide crosscountry comparable estimates of the willingness to accept a covid-19 vaccine in six Sub-Saharan African countries.

\section{Methods}

We use data from six national high-frequency phone surveys from countries representing 38\% of the Sub-Saharan African population (Burkina Faso, Ethiopia, Malawi, Mali, Nigeria, and Uganda). Samples are drawn from large, nationally representative sampling frames providing a rich set of demographic and socio-economic characteristics by which we disaggregate our analysis. Using a set of re-calibrated survey weights, our analysis adjusts for the selection biases common in remote surveys.

\section{Results}

Acceptance rates in the six Sub-Saharan African countries studied are generally high, with at least four in five people willing to be vaccinated in all but one country. Vaccine acceptance ranges from nearly universal in Ethiopia $(97.9 \%, 97.2 \%$ to 98.6\%) to below what would likely be required for 
medRxiv preprint doi: https://doi.org/10.1101/2021.06.28.21259320; this version posted July 2, 2021. The copyright holder for this preprint (which was not certified by peer review) is the author/funder, who has granted medRxiv a license to display the preprint in perpetuity. It is made available under a CC-BY-ND 4.0 International license .

herd immunity in Mali $(64.5 \%, 61.3 \%$ to $67.8 \%)$. We find little evidence for systematic differences in vaccine hesitancy by sex or age but some clusters of hesitancy in urban areas, among the better educated, and in richer households. Safety concerns about the vaccine in general and its side effects emerge as the primary reservations toward a covid-19 vaccine across countries.

\section{Conclusions}

Our findings suggest that limited supply, not inadequate demand, likely presents the key bottleneck to reaching high covid-19 vaccine coverage in Sub-Saharan Africa. To turn intent into effective demand, targeted communication campaigns bolstering confidence in the safety of approved vaccines and reducing concerns about side effects will be crucial to safeguard the swift progression of vaccine rollout in one of the world's poorest regions.

\section{What is already known?}

- Estimates of vaccine acceptance in high- and middle-income countries have found rates to cluster around $70 \%$ with considerable cross-country variation.

- As vaccine rollout is severely lagging, low-income countries and particularly SubSaharan Africa (SSA) with almost two thirds of the global poor population remain exposed to covid-19 and its impacts on lives and livelihoods.

- Much of the current debate on vaccination campaigns in SSA focuses on supply-chain and financial factors, yet there is a dearth of robust, comparable evidence on covid-19 vaccine hesitancy in these countries.

\section{What are the key findings?}

- Covid-19 vaccine acceptance is high in six Sub-Saharan African countries with an estimated four in five people or more in all but one study country willing to take an approved, free vaccine.

- Clusters of hesitancy vary by country but generally comprise urban areas, richer households, and those with more education.

\section{What do the new findings imply?}

- Limited supply, rather than inadequate demand, likely presents the key bottleneck to achieving high covid-19 vaccine coverage in Sub-Saharan Africa.

- To reach mass coverage, information campaigns should bolster confidence in vaccine safety and alleviate concerns about side effects. 
medRxiv preprint doi: https://doi.org/10.1101/2021.06.28.21259320; this version posted July 2, 2021. The copyright holder for this preprint (which was not certified by peer review) is the author/funder, who has granted medRxiv a license to display the preprint in perpetuity. It is made available under a CC-BY-ND 4.0 International license .

\section{Introduction}

As vaccination campaigns in high-income countries are accelerating, large swathes of the global population living in low- and middle-income countries remain severely exposed to the novel coronavirus disease (covid-19).[1] Sub-Saharan Africa is home to 433 million people living below the international absolute poverty line (about two thirds of the global poor population).[2] For these populations, non-pharmaceutical interventions to curb the spread of the disease impinged on already precarious livelihoods.[4] Furthermore, the region is characterized by high prevalence of comorbidities, and public health systems that are ill equipped to stave off the burden of mass infection.[1,3,4] Reaching large-scale vaccination coverage in Sub-Saharan Africa (SSA) is thus pivotal in the global effort to halt the spread of the disease and limit its toll on lives and livelihoods.[5-7]

Recent calls to action by international stakeholders and a growing body of scholarly research focus on supply-chain and financial factors to safeguard sufficient vaccine availability in SSA. The COVAX initiative aims to provide doses sufficient to vaccinate up to $20 \%$ of the population in the region, far below the target population required for a coverage of $60 \%$, or 321.5 million individuals.[8,9] Still, this would leave an estimated financing gap of over \$10 billion in SSA.[10] A June 2021 resolution from the G7 pledging one billion covid-19-vaccine doses for low-income countries offers hope for those supply gaps being filled. While these considerations concern the availability of vaccines, another key factor for the success of vaccination campaigns in SSA is the willingness to be vaccinated within the population. Yet, there is a dearth of large-scale evidence on vaccine acceptance in low income countries in general and SSA in particular.

Based on a cross-country comparable sample with national scope from six Sub-Saharan African countries, we fill this knowledge gap by providing estimates of vaccine acceptance for a population representative of around 416 million people, 38\% of the population of Sub-Saharan Africa.[11] Drawing on the high frequency phone surveys (HFPS) based on pre-pandemic sampling frames from nationally representative, face-to-face household surveys supported by the World Bank's Living Standard Measurement Study - Integrated Survey on Agriculture (LSMS-ISA), we are able to link covid-19 vaccine acceptance rates to a rich set of demographic and socio-economic characteristics. Along with recalibrated sampling weights, this allows our study to provide robust insights into the likelihood of the current efforts to ensure sufficient supply of vaccination doses to also meet adequate demand in SSA, identify clusters of hesitancy, and contribute to a swift rollout of vaccination campaigns where they will be needed most.

\section{Methods}

\section{Data and survey instrument}

We use data from the national longitudinal high-frequency phone surveys on covid-19 (HFPS) conducted in Burkina Faso, Ethiopia, Malawi, Mali, Nigeria, and Uganda. Survey implementation was led by the respective national statistical agencies, the Burkina Faso National Institute of Statistics and Demography; Laterite Ethiopia in collaboration with the Central Statistical Agency of Ethiopia; Malawi National Statistical Office; Mali National Institute of Statistics; Nigeria 
medRxiv preprint doi: https://doi.org/10.1101/2021.06.28.21259320; this version posted July 2, 2021. The copyright holder for this preprint (which was not certified by peer review) is the author/funder, who has granted medRxiv a license to display the preprint in perpetuity. It is made available under a CC-BY-ND 4.0 International license .

Bureau of Statistics; and Uganda Bureau of Statistics; and supported by the World Bank Living Standards Measurement Study and the Poverty and Equity Global Practice. The HFPS on covid19 have been implemented monthly since May 2020, aiming to gauge the impact of the covid-19 pandemic on individual and household attitudes, socioeconomic and health outcomes.[12]

The HFPS rounds in which vaccine hesitancy was covered in a cross-country comparable fashion were conducted in September 2020 (Ethiopia, round 6), October-November 2020 (Malawi, round 5; Mali, round 5; and Nigeria, round 6) and December 2020 (Burkina Faso, round 5; and Uganda, round 4). The primary survey questions of interest, posed to each phone survey respondent, was: 'If an approved vaccine to prevent coronavirus was available right now at no cost, would you agree to be vaccinated?' with response options 'yes', 'no', and 'not sure ';. If respondents answered 'no' or 'not sure', this was followed up by a question about possible reasons for refusing to be vaccinated: 'What are the reasons you would not agree to be vaccinated?', with response options:

(1) 'I don't think it will be safe'

(2) 'I am worried about the side effects'

(3) 'It is against my religion'

(4) 'I am not at risk of contracting covid-19'

(5) 'I don't think it will work'

(6) 'I am against vaccine in general'

(7) Other

We are interested in the association between willingness to be vaccinated and a standard set of demographic and socioeconomic variables, such as gender, age, income, and education. These are available for respondents either from the HFPS directly or from pre-covid-19 face-to-face (FtF) surveys, which served as the sampling frames for the HFPS. We further draw on multiple rounds of the HFPS to create variables on respondents' attitudes towards the covid-19 emergency and how it has affected them and their families. These include willingness to be tested for covid-19, rating of government response, and whether households received any government assistance during the pandemic. The data as well as survey instruments and basic information documents are available publicly on the World Bank Microdata Library under the High-Frequency Phone Survey collection.[13]

\section{Sampling and sample representativeness}

The samples for the HFPS were drawn from mobile phone numbers recorded during data collection for nationally representative face-to-face $(\mathrm{FtF})$ household surveys implemented prior to the covid19 pandemic with support from the World Bank Living Standards Measurement Study - Integrated Surveys on Agriculture (LSMS-ISA) program. Specifically, the Burkina Faso Enquête harmonisée sur les conditions de vie des ménages 2018/19, Ethiopia Socioeconomic Survey 2018/19, Malawi Integrated Household Panel Survey 2019, Mali Enquête harmonisée sur les conditions de vie des ménages 2018/19, Nigeria General Household Survey - Panel 2018/19, and Uganda National Panel Survey 2019/20. At least one phone number was recorded for all households with access to a phone, including through a contact person outside of the household, such as a friend or neighbor. For the HFPS, Ethiopia, Malawi, and Uganda attempted to contact all households with available 
phone numbers, while Burkina Faso, Nigeria and Mali selected a random sub-sample of phone numbers to call (Table A.1).

In the absence of universal access to a mobile phone, the HFPS households are likely to be selected samples of the nationally representative FtF survey samples of households.[14] The publicly available HFPS datasets therefore come with recalibrated household survey weights to counteract potential selection biases. The recalibration model takes advantage of the rich information on households with and without access to a phone from the pre-covid-19 FtF surveys [15,16] and follows a methodology proposed in a reference methodological paper on this subject.[17] The effectiveness of this weight recalibration in overcoming selection biases has been documented in HFPS data from four of the six countries we study, such that household-level estimates based on the HFPS data can be broadly considered representative at the national level.[14]

Further, the HFPS survey questions on vaccinations were asked only to the household's main respondent, who had to be 15 or older, as it is impractical to interview all individuals in a household in a phone survey. The selection of main respondents was not randomized so that the group of respondents is likely not representative of the general population of adults at the individual level. Rather, respondents tend to be household heads or their spouses, better educated and slightly older, as a recent study documents.[18] An additional recalibration of survey weights for individual-level analysis improves representativeness, but cannot overcome respondent selection biases in all variables and increases the variance of the estimates.[18]

Considering these potential shortfalls in the representativeness of our data, we present our main results first with the standard HFPS household weights and then, as a robustness and sensitivity check for potential respondent selection biases, with the recalibrated individual-level weights. A summary of unweighted individual characteristics of FtF adults vis-à-vis HFPS adults is presented in Table A.3.

\section{Statistical analysis}

The statistical analysis proceeds in several steps. First, we estimate the weighted mean of willingness to get vaccinated by country, and within countries by sex of respondent, residence (urban and rural) and income quintile, as well as reasons for vaccine hesitancy, using the recalibrated household weights. Second, we explore how individual and household characteristics, such as education and expenditure, correlate with the willingness to get vaccinated in a set of multivariate logit regressions, again using household weights. To assess how much the differences in the attributes of respondents vis-à-vis the general adult population may affect the representativeness of our results, we assess the sensitivity of the results to using individual-level recalibrated weights instead of the public-use household weights (see Discussion).[18]

\section{Patient and public involvement}

This research did not involve consultation with patients or the public. 
medRxiv preprint doi: https://doi.org/10.1101/2021.06.28.21259320; this version posted July 2, 2021. The copyright holder for this preprint (which was not certified by peer review) is the author/funder, who has granted medRxiv a license to display the preprint in perpetuity. It is made available under a CC-BY-ND 4.0 International license .

\section{Results}

\section{Descriptive results}

Overall, we find high levels of willingness to be vaccinated: Acceptance is estimated to be nearly universal in Ethiopia at $97.9 \%$ (95\% confidence interval $97.2 \%$ to $98.6 \%$ ) and very high in Nigeria (86.2\%, $83.9 \%$ to $88.5 \%)$, Uganda $(84.5 \%, 82.2 \%$ to $86.8 \%)$, Malawi $(82.7 \%, 80.0 \%$ to $85.4 \%)$, and Burkina Faso (79.5\%, $76.9 \%$ to $82.1 \%$ ). In these countries at least four in five respondents would agree to be vaccinated if an approved vaccine was made available for free to them (Figure 1, Panel A). Acceptance is somewhat lower only in Mali where less than two thirds of respondents $(64.5 \%, 61.3 \%$ to $67.8 \%)$ reported their willingness to be vaccinated. Notably, Mali is also the only country in which a non-negligible share $(12.4 \%)$ is uncertain about their answer, a fact that accounts for the majority of the lower acceptance rates in Mali. For the following analysis, we focus on acceptance rates and do not distinguish between respondents rejecting to be vaccinated and those that are not sure. Pooling the data from all countries and weighting them by their respective popualtion sizes yields an overall mean acceptance rate of $87.6 \%$ (86.4\% to $88.8 \%$ ) across the six countries (Table A.2).

Figure 1: Vaccine hesitancy overall, by sex, by residence, and by expenditure

\section{If an approved vaccine to prevent coronavirus was available right now at no cost, would you agree to be vaccinated?}
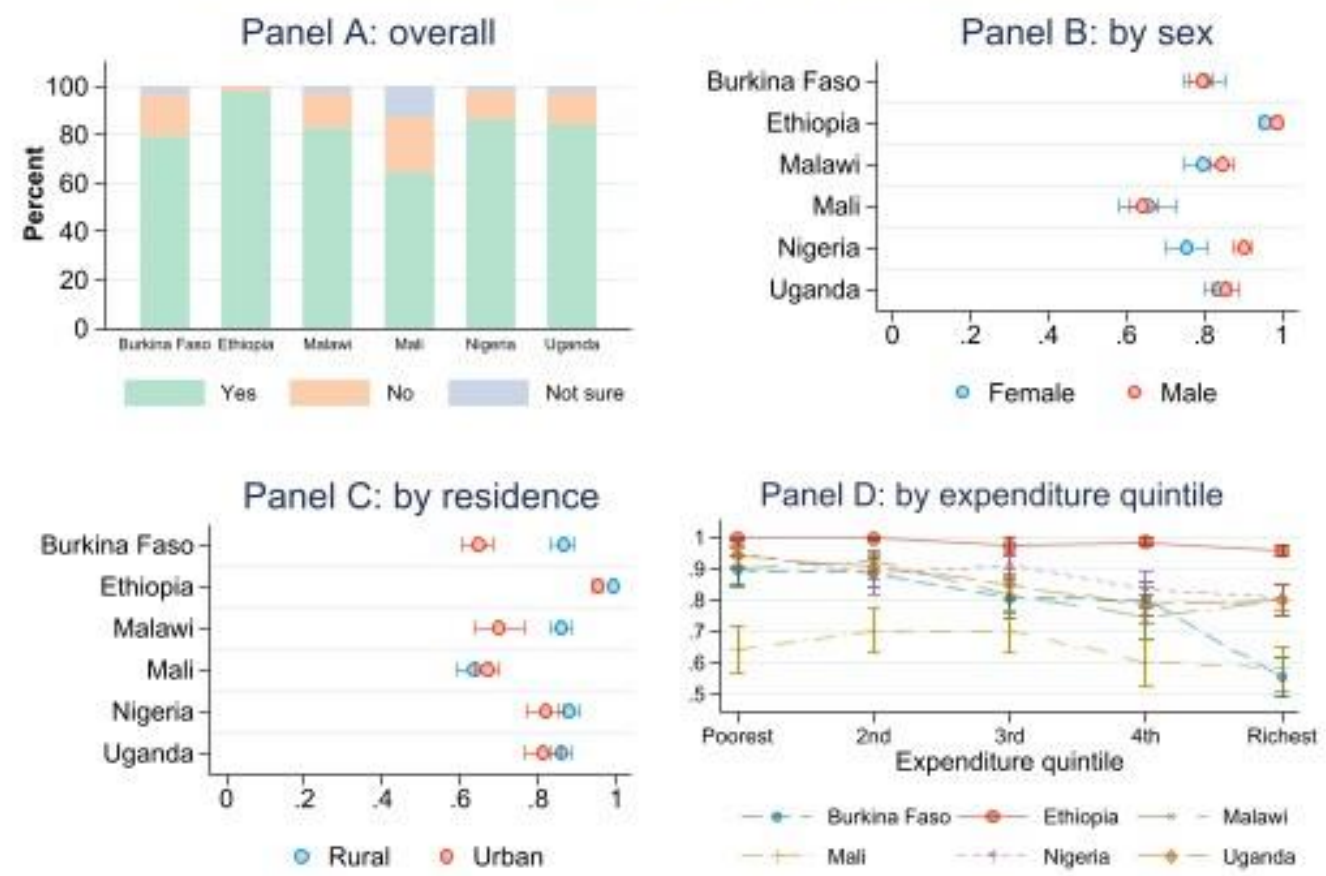

In Panel B of Figure 1, we disaggregate acceptance rates by respondent sex. Except for Nigeria where acceptance is statistically significantly higher among male than female respondents $(90.1 \%$, $87.6 \%$ to $92.6 \%$ and $75.7 \%, 70.4 \%$ to $80.9 \%$, respectively) and in Ethiopia where there is a small, yet statistically significant difference $(98.7 \%, 97.9 \%$ to $99.4 \%$ and $95.8 \%, 94.1 \%$ to $97.5 \%$, 
medRxiv preprint doi: https://doi.org/10.1101/2021.06.28.21259320; this version posted July 2, 2021. The copyright holder for this preprint (which was not certified by peer review) is the author/funder, who has granted medRxiv a license to display the preprint in perpetuity. It is made available under a CC-BY-ND 4.0 International license .

respectively), we do not find answers to differ between men and women. Similarly, Panel C reports differences in willingness to be vaccinated against covid-19 between rural and urban areas with higher acceptance in rural areas in Burkina Faso, Ethiopia, and Malawi at the 95\% confidence level. One distinct feature of our data is the ability to tap into the rich pre-covid-19 baseline data from the face-to-face household surveys that served as sampling frames. This way, we are able to determine respondent household's position in the national expenditure distribution and disaggregated acceptance rates by expenditure quintile (Panel D). We generally find a downward sloping pattern in which acceptance is higher among poorer households and lowest among the richest households. This pattern is particularly evident in Burkina Faso but also noteworthy in Uganda and Nigeria. Conversely, acceptance is high throughout all expenditure quintiles in Ethiopia and not significantly lower for the richest two quintiles in Mali.

Figure 2: Reasons for covid-19 vaccine hesitancy

Burkina Faso

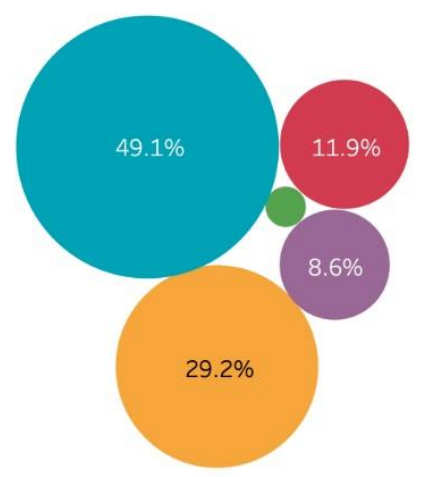

Mali

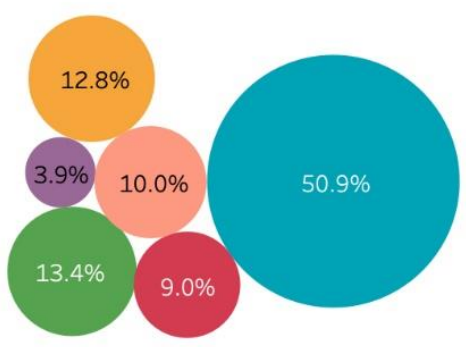

Reason

Don't think it will be safe

Worried about side effects

Don't think it will work

against vaccine in general

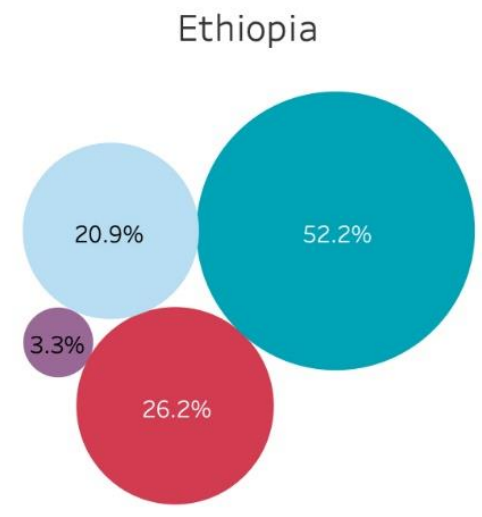

Nigeria

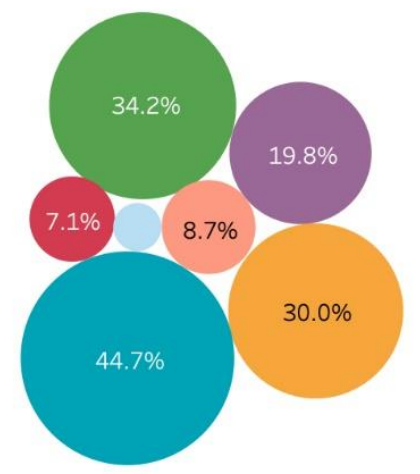

Not at risk of contracting Covid-19

Against my religion

Other reason

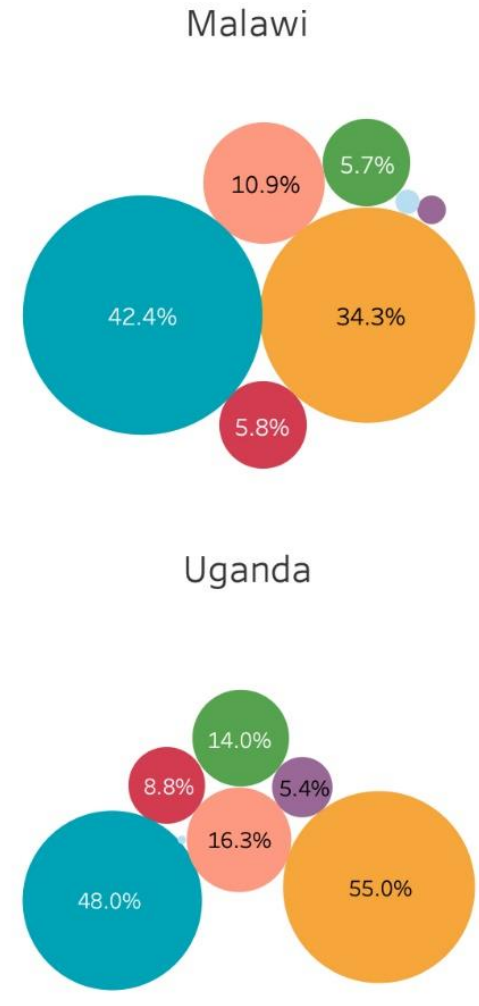

For those respondents who were hesitant to be vaccinated, the survey asked to provide a reason. From Figure 2, it is evident that safety concerns were paramount ranging from $53.7 \%(36.1 \%$ to $71.3 \%$ ) of those reporting they would refuse to be vaccinated in Burkina Faso to $42.4 \%$ (33.8\% to $50.9 \%$ ) in Malawi, despite the wording of the questions making it explicit that the vaccine would 
medRxiv preprint doi: https://doi.org/10.1101/2021.06.28.21259320; this version posted July 2, 2021. The copyright holder for this preprint (which was not certified by peer review) is the author/funder, who has granted medRxiv a license to display the preprint in perpetuity. It is made available under a CC-BY-ND 4.0 International license .

be officially approved. Other notable reasons include worries about the potential side effects of the vaccine (between $55 \%$ (46.9\% to $63.0 \%$ ) in Uganda and $12.8 \%$ (9.1\% to $16.5 \%$ ) in Mali) and the belief not to be at risk of contracting the virus $(34.2 \%(25.2 \%$ to $43.3 \%)$ in Nigeria to $0.1 \%(0 \%$ to $2.1 \%$ ) in Burkina Faso).

\section{Correlates of hesitancy}

Exploiting the richness of our data, we can explore correlational patterns between willingness to be vaccinated for covid-19 and a large set of respondent and household characteristics. Table 1 confirms in a multivariate setting the patterns observed graphically earlier. In general, men tend to be more willing to take the vaccine, though we only detect a statistically significant effect in Nigeria. Respondents in urban areas are more skeptical with significant differences in Burkina Faso, Ethiopia, and Malawi.

An association we observe across countries is between education and vaccine hesitancy. In Burkina Faso, Ethiopia, Malawi, and Nigeria, those with more years of education are significantly less willing to be vaccinated while coefficients signs point in the same direction in Mali and Uganda but are not significant. Lastly, we do not find a pattern according to respondents' age and a mixed picture according to the role of the respondent in the household. Here, household heads which constitute the majority of our sample (see Table A.3) are more willing to be vaccinated in Ethiopia, more hesitant in Mali, and not significantly different from other household members in the remaining four cases.

A pattern we observe in several countries is a higher hesitancy toward the vaccine in richer households compared to the poorest expenditure quintile, with coefficients significant in Mali and Uganda for the richest two quintiles, for the top quintile in Burkina Faso and Nigeria, and the third and fourth quintiles in Malawi.

The data further show a strong association between vaccine hesitancy and the willingness to be tested for covid-19 suggesting similar underlying reasons for (or against) testing and getting vaccinated. Another hypothesis we explore is whether there is an association between the receipt of some assistance during the pandemic, e.g. through one of the large-scale social protection programs launched to combat the fallout of the pandemic, and willingness to receive a free, approved vaccine against covid-19. While coefficient signs mostly point to a positive association, the effect is not statistically significantly different from zero despite all countries in our sample launching some social protection response to the crisis.[19]

A last hypothesis we pursue concerns the relationship between trust in and satisfaction with the government and willingness to be vaccinated. For example, more skeptical individuals toward the government or those dissatisfied with its crisis management may be more reluctant to accept a state-provided vaccine.[20,21] We only have data on trust in the government's crisis management in Malawi and satisfaction in Mali and Nigeria but find our hypotheses confirmed in bivariate logistic regressions (Table A.6). However, after controlling for all other factors in Table 1, coefficients are no longer significant. 
Table 1: Correlates of hesitancy.

\section{Correlates of hesitancy - marginal effects from multivariate logit regressions}

\begin{tabular}{|c|c|c|c|c|c|c|}
\hline VARIABLES & $\begin{array}{c}\text { (1) } \\
\text { Burkina Faso }\end{array}$ & $\begin{array}{c}\text { (2) } \\
\text { Ethiopia }\end{array}$ & $\begin{array}{c}\text { (3) } \\
\text { Malawi }\end{array}$ & $\begin{array}{l}\text { (4) } \\
\text { Mali }\end{array}$ & $\begin{array}{c}(5) \\
\text { Nigeria } \\
\end{array}$ & $\begin{array}{c}\text { (6) } \\
\text { Uganda }\end{array}$ \\
\hline Respondent is male & $\begin{array}{l}-0.0388 \\
(0.0340)\end{array}$ & $\begin{array}{c}0.00913 \\
(0.00569)\end{array}$ & $\begin{array}{c}0.0419 \\
(0.0311)\end{array}$ & $\begin{array}{c}0.0522 \\
(0.0413)\end{array}$ & $\begin{array}{c}0.0932 * * * \\
(0.0268)\end{array}$ & $\begin{array}{c}0.0179 \\
(0.0224)\end{array}$ \\
\hline Lives in urban area & $\begin{array}{c}-0.0878^{* * * *} \\
(0.0294)\end{array}$ & $\begin{array}{l}-0.0191 * * \\
(0.00858)\end{array}$ & $\begin{array}{c}-0.0880^{* * * *} \\
(0.0289)\end{array}$ & $\begin{array}{c}0.0237 \\
(0.0286)\end{array}$ & $\begin{array}{l}-0.0151 \\
(0.0222)\end{array}$ & $\begin{array}{c}0.0168 \\
(0.0212)\end{array}$ \\
\hline Years of education & $\begin{array}{c}-0.00610 * * \\
(0.00252)\end{array}$ & $\begin{array}{l}-0.00137 * \\
(0.000734)\end{array}$ & $\begin{array}{c}-0.0135 * * * \\
(0.00330)\end{array}$ & $\begin{array}{l}-0.00452 \\
(0.00288)\end{array}$ & $\begin{array}{c}-0.00680 * * \\
(0.00286)\end{array}$ & $\begin{array}{l}-0.00164 \\
(0.00283)\end{array}$ \\
\hline Age group 30-60 yrs & $\begin{array}{l}-0.0166 \\
(0.0365)\end{array}$ & $\begin{array}{c}0.00494 \\
(0.00838)\end{array}$ & $\begin{array}{c}0.0152 \\
(0.0312)\end{array}$ & $\begin{array}{c}0.0297 \\
(0.0458)\end{array}$ & $\begin{array}{c}0.0436 \\
(0.0366)\end{array}$ & $\begin{array}{c}-0.0274 \\
(0.0269)\end{array}$ \\
\hline Age group $60+$ yrs & $\begin{array}{c}0.0446 \\
(0.0435)\end{array}$ & $\begin{array}{l}0.00700 \\
(0.0141)\end{array}$ & $\begin{array}{l}-0.0140 \\
(0.0505)\end{array}$ & $\begin{array}{l}-0.0273 \\
(0.0584)\end{array}$ & $\begin{array}{c}0.0499 \\
(0.0461)\end{array}$ & $\begin{array}{c}0.0179 \\
(0.0341)\end{array}$ \\
\hline Household head & $\begin{array}{c}0.0558 \\
(0.0376)\end{array}$ & $\begin{array}{l}0.0171 * * \\
(0.00776)\end{array}$ & $\begin{array}{c}-0.00894 \\
(0.0381)\end{array}$ & $\begin{array}{c}-0.0886^{* *} \\
(0.0450)\end{array}$ & $\begin{array}{l}-0.0266 \\
(0.0325)\end{array}$ & $\begin{array}{r}-0.00563 \\
(0.0242)\end{array}$ \\
\hline Household Size & $\begin{array}{c}0.00310 \\
(0.00378)\end{array}$ & $\begin{array}{l}0.000705 \\
(0.00152)\end{array}$ & $\begin{array}{c}0.0103 * \\
(0.00557)\end{array}$ & $\begin{array}{l}-0.00536 \\
(0.00358)\end{array}$ & $\begin{array}{c}0.00286 \\
(0.00580)\end{array}$ & $\begin{array}{c}0.00631 \\
(0.00476)\end{array}$ \\
\hline Expenditure, 2nd quintile & $\begin{array}{c}0.0230 \\
(0.0426)\end{array}$ & $\begin{array}{l}0.00677 \\
(0.0102)\end{array}$ & $\begin{array}{c}0.0198 \\
(0.0437)\end{array}$ & $\begin{array}{c}0.0307 \\
(0.0441)\end{array}$ & $\begin{array}{l}-0.0677 \\
(0.0564)\end{array}$ & $\begin{array}{l}-0.0302 \\
(0.0319)\end{array}$ \\
\hline Expenditure, 3rd quintile & $\begin{array}{l}-0.0568 \\
(0.0430)\end{array}$ & $\begin{array}{l}-0.0216 \\
(0.0195)\end{array}$ & $\begin{array}{c}-0.0953^{*} \\
(0.0516)\end{array}$ & $\begin{array}{c}0.0166 \\
(0.0431)\end{array}$ & $\begin{array}{l}0.00195 \\
(0.0427)\end{array}$ & $\begin{array}{l}-0.0500 \\
(0.0308)\end{array}$ \\
\hline Expenditure, 4th quintile & $\begin{array}{l}-0.0357 \\
(0.0442)\end{array}$ & $\begin{array}{l}-0.00381 \\
(0.0103)\end{array}$ & $\begin{array}{l}-0.116^{* *} \\
(0.0473)\end{array}$ & $\begin{array}{c}-0.0932^{*} \\
(0.0501)\end{array}$ & $\begin{array}{l}-0.0623 \\
(0.0458)\end{array}$ & $\begin{array}{c}-0.107 * * * * \\
(0.0340)\end{array}$ \\
\hline Expenditure, 5th (richest) quintile & $\begin{array}{c}-0.164 * * * * \\
(0.0534)\end{array}$ & $\begin{array}{l}-0.0111 \\
(0.0108)\end{array}$ & $\begin{array}{l}-0.0106 \\
(0.0457)\end{array}$ & $\begin{array}{r}-0.135 * * \\
(0.0536)\end{array}$ & $\begin{array}{c}-0.0696 * \\
(0.0421)\end{array}$ & $\begin{array}{c}-0.0754 * * \\
(0.0346)\end{array}$ \\
\hline Willing to be tested for covid-19 & $\begin{array}{c}0.208^{* * * *} \\
(0.0313)\end{array}$ & $\begin{array}{c}0.0619 * * * \\
(0.00889)\end{array}$ & $\begin{array}{c}0.253^{* * *} \\
(0.0389)\end{array}$ & $\begin{array}{r}0.461^{* * * *} \\
(0.0172)\end{array}$ & $\begin{array}{c}0.221 * * * \\
(0.0221)\end{array}$ & $\begin{array}{c}0.340 * * * \\
(0.0254)\end{array}$ \\
\hline HH received assistance during covid-19 & $\begin{array}{c}0.0490 \\
(0.0470)\end{array}$ & $\begin{array}{c}0.00607 \\
(0.00886)\end{array}$ & $\begin{array}{r}-0.00457 \\
(0.0322)\end{array}$ & $\begin{array}{r}-0.00728 \\
(0.0618)\end{array}$ & $\begin{array}{c}0.0152 \\
(0.0220)\end{array}$ & $\begin{array}{c}0.0307 \\
(0.0194)\end{array}$ \\
\hline Gov't not trustworthy & & & $\begin{array}{l}-0.0455 \\
(0.0291)\end{array}$ & & & \\
\hline Satisfied with gov't response & & & & $\begin{array}{c}0.0354 \\
(0.0450)\end{array}$ & $\begin{array}{c}0.0279 \\
(0.0202)\end{array}$ & \\
\hline Observations & 1,742 & 2,654 & 1,542 & 1,591 & 1,703 & 2,106 \\
\hline Pseudo R2 & 0.183 & 0.308 & 0.137 & 0.265 & 0.218 & 0.233 \\
\hline
\end{tabular}

Robust standard errors in parentheses. $* * * \mathrm{p}<0.01, * * \mathrm{p}<0.05, * \mathrm{p}<0.1$. Weighted logit regressions with willingness to take a free, approved vaccine as dependent variable. 
medRxiv preprint doi: https://doi.org/10.1101/2021.06.28.21259320; this version posted July 2, 2021. The copyright holder for this preprint (which was not certified by peer review) is the author/funder, who has granted medRxiv a license to display the preprint in perpetuity. It is made available under a CC-BY-ND 4.0 International license .

\section{Discussion Principal findings}

Our study uses cross-country comparable data from the national longitudinal high frequency phone surveys on covid-19 (HFPS) in six Sub-Saharan African countries to estimate acceptance rates for an approved, free covid-19 vaccine. By linking phone survey data to the nationally representative, large-scale, face-to-face household surveys that served as sampling frames for the HFPS, we provide robust estimates of the willingness to be vaccinated against covid-19 across a diverse set of demographics and respondent and household characteristics. Our headline results indicate high acceptance rates with at least four in five respondents signaling their willingness to be vaccinated in all but one of the countries studied. There is cross-country variation, with willingness to be vaccinated ranging from $64.5 \%$ in Mali $(61.3 \%$ to $67.8 \%$ ), where a further $12.4 \%$ are yet undecided, to near universal acceptance in Ethiopia (97.9\%, 97.2\% to 98.6\%). We also find little evidence for systematic differences in vaccine hesitancy across gender or age but some notable clusters of hesitancy in urban areas, among those better educated, and in richer households. Across countries, safety concerns about the vaccine in general and its side effects specifically emerged as the primary reservations toward a covid-19 vaccine.

\section{Strengths and comparison with other studies}

In relation to the existing literature, our study has several advantages in the domains of coverage and sample selection, richness of the data, and analytical depth. In terms of coverage, our study focuses on a region with yet scant evidence on willingness to be vaccinated against covid-19. Importantly, the data we assemble are cross-country comparable and without exception based on large, nationally representative sampling frames from pre-covid, face-to-face household surveys. This allows us to calibrate survey weights that adjust for the coverage and non-response biases that plague other studies at a time where regular face-to-face data collection nearly came to a complete halt.[22-24] Furthermore, our study is unique in that the pre-existing survey data from which our samples are drawn allow us to tap into a rich set of baseline individual and household characteristics. This facilitates a more rigorous analysis and disaggregation of acceptance rates, including, for instance, households' position in the national (pre-crisis) expenditure distribution, than has been possible previously. Our study thus stands out as a fully cross-country comparable, multivariate, and inferential analysis of vaccine hesitancy on the African continent.

Compared to our study, previous studies that analyze covid-19 vaccine acceptance rates and the reasons for refusal predominantly (i) focus on middle- and high-income countries, (ii) represent single-country or not cross-country comparable samples, (iii) study particular subpopulations such as university students, healthcare workers, or participants of unrelated pre-covid studies, (iv) rely on non-random sampling, or (v) can only draw on a small set of demographics and characteristics to disaggregate their analysis.[18,25-35]

A cross-country study of 19 countries with samples obtained from commercial online panel providers found $71.5 \%$ of respondents willing to be vaccinated against covid-19 with a rate of $65.2 \%$ in Nigeria as the only low-income country.[36] Similarly, a literature review of 31 studies 
medRxiv preprint doi: https://doi.org/10.1101/2021.06.28.21259320; this version posted July 2, 2021. The copyright holder for this preprint (which was not certified by peer review) is the author/funder, who has granted medRxiv a license to display the preprint in perpetuity. It is made available under a CC-BY-ND 4.0 International license .

covering 33 countries found covid-19 vaccine acceptance rates at or above $70 \%$ among studies focusing on the general population but also large regional and intra-regional differences and a dearth of evidence particularly from Sub-Saharan Africa.[37]

Few studies explicitly focus on acceptance rates in the poorest countries. Assembling an amalgamation of data samples with different sources, sampling methodologies, and coverage, one study finds generally high acceptance rates in ten LMICs in Asia, Africa, and South America.[38] Among countries also covered in our study, acceptance rates are lower than what we find in Burkina Faso (66.5\%, national phone sample obtained by random digit dialing) and Nigeria (76.2\%, random sample of residents of one state from telephone list), close in urban Uganda (76.5\%, random sample of households in Kampala), and very similar in rural Uganda (85.8\%, nonrandom sample of women in 13 districts).[38] However, in those studies the ability to correct for various sample selection biases is likely limited in the absence of baseline nationally representative sampling frames. Another study in 15 African countries, including Burkina Faso, Malawi, Nigeria, Uganda (all face-to-face interviewing), and Ethiopia (telephone survey) found estimates for the countries also covered in our study mostly in the vicinity of our weighted figures (Ethiopia 94\%, Uganda 87.5\%, Burkina Faso 86\%, Malawi 82.7\%, Nigeria 76\%).[39,40] Notably, average sample sizes are roughly half of our study's and there is a lack of analytical detail impeding a robust inference of cross-country and -demographic findings. Lastly, our results contrast with a recent Afrobarometer study based on in-person interviews in five West African countries, none of which are also included in our sample. In relation to our study, the study's analysis is purely descriptive and reports low acceptance rates of $40 \%$ on average.[21] Similar to what we find, the study cites trust in vaccine safety as the key driver of hesitancy, a result that is further corroborated in the literature.[21,28,36,38,40] Furthermore, the small systematic differences we observe according to gender and age are in line with most previous findings in low-income countries as is a tendency for higher acceptance in rural areas.[21,36,38,40] As with overall acceptance rates, our finding of higher hesitancy among the more educated is in line with two of the studies covering Sub-Saharan Africa [38,39] while another study finds mixed evidence.[21] No other study we are aware of across LMICs (and in fact few across countries of any income classification) assess vaccine acceptance according to economic status in a manner comparable with the expenditure data we can access from the pre-covid-19 sampling frames.

\section{Limitations of this study}

This study uses data from high-frequency phone surveys (HFPS) with national coverage along with sampling weights specifically recalibrated for the phone surveys to be nationally representative. The weights were shown to be effective at achieving nationally representative estimates at the household level.[14] However, willingness to be vaccinated is primarily not a household-level attribute but an individual decision, though it is reasonable to expect considerable intra-household correlation in attitudes towards vaccination. Phone survey respondents in our data are not specifically selected to be representative of all individuals and that may limit the population-level representativeness of the results we report. Recalibration of survey weights at the individual level can partially but not fully address this concern.[18] To gauge how sensitive our results are to respondent selection biases in individual-level data, we compare the estimates with 
medRxiv preprint doi: https://doi.org/10.1101/2021.06.28.21259320; this version posted July 2, 2021. The copyright holder for this preprint (which was not certified by peer review) is the author/funder, who has granted medRxiv a license to display the preprint in perpetuity. It is made available under a CC-BY-ND 4.0 International license .

household-level weights to the same estimates with individual-level weights. In this test, large deviations between those two sets of estimates would indicate that selection biases affect our results in a fundamental way. However, we find only limited change in the estimates, regardless of which weight is used: in over three quarters of cases, deviations do not exceed two percentage points, including the headline findings on willingness to be vaccinated in all study countries, and we find only three instances where the differences exceed five points (Variable ' $Q 5$ ' $5.8 \%$ in Burkina Faso; 'Q4' 6.2\% in Mali; 'Q3' 6.0\% in Nigeria; Table A.4). The results from the multivariate logit regression model are also robust to the use of household or individual-level weights. This is true especially of the cross-country findings for urban and richer households and willingness to get tested for covid-19: the point estimates tend to be slightly larger when using individual-level compared to household-level weights but they are of comparable magnitude and in most cases retain statistical significance (Table A.5). In contrast, the findings on education have similar point estimates whether we use household or individual-level weights, but with individuallevel weights they retain statistical significance only in Malawi. This is likely because individuallevel weight recalibration increases the variance of the estimates. All in all, we take this set of tests to indicate the robustness of our results to concerns around respondent selection.

Another potential limitation is the possible malleability of attitudes towards vaccinations, which may have changed, and continue to change, in light of the development of various vaccines and the relative success these appear to have in stemming the pandemic in other parts of the world. Future research is needed to determine evolving attitudes in Africa towards being vaccinated and their interactions with vaccine supply and availability.

\section{Conclusions and policy implications}

Our headline results of high vaccine acceptance in a cross-country comparable sample of six SubSaharan African countries suggests that limited supply, not inadequate demand, is likely to present the key bottleneck to reaching high covid-19 vaccine coverage in the region. As willingness to be vaccinated does not automatically translate into vaccine-seeking behavior, public authorities need to turn intent into effective demand as vaccine rollout progresses. [41] For this, our study identifies some indicative pockets of hesitancy, particularly in Mali, urban Burkina Faso and Malawi, among women in Nigeria, and for richer households and those with more education. As many of these population groups are easier to reach early in the vaccine rollout process, yet are also better reachable through targeted communication, campaigns that raise acceptance for a covid-19 vaccine in these clusters will be key. These should focus on resolving concerns about side effects and bolster confidence in the safety of approved covid-19 vaccines in order to reach mass coverage and end the pandemic swiftly and everywhere. 


\section{Contributors}

All authors had full access to all of the data in the study and take responsibility for the integrity of the data and the accuracy of the data analysis. All authors were responsible for its conception and design. YM, PW, and SK were responsible for the preparation and analysis of the data and all authors contributed to their interpretation. YM and PW drafted the manuscript and AZ made critical revision of the manuscript for important intellectual content. SK and AZ conceptualized an early version. AZ is the guarantor. The corresponding author attests that all listed authors meet authorship criteria and that no others meeting criteria have been omitted.

\section{Funding}

Funding for the analysis comes from the World Bank Multi-Donor Trust Fund for Integrated Household and Agricultural Surveys in Low and Middle-Income Countries (TF072496). The funders had no role in study design, data collection, analysis, interpretation of the data, decision to publish, or preparation of the manuscript.

\section{Competing interests}

All authors have completed the ICMJE uniform disclosure form at www.icmje.org/coi_disclosure.pdf and declare: no support from any organization for the submitted work; no financial relationships with any organizations that might have an interest in the submitted work in the previous three years; no other relationships or activities that could appear to have influenced the submitted work.

\section{Ethics approval}

Each phone survey was implemented by the respective national statistical office (NSO), except for Ethiopia where a private firm was the implementing agency. In Burkina Faso, Malawi, Mali, Nigeria, and Uganda, the NSO conducts the survey as the sole official statistical authority in the country and in accordance with the respective National Statistical Act, which exempts the NSO from institutional ethics approvals. Informed consent was received from all survey respondents in each country. The World Bank does not require institutional ethics approval for household surveys that are partly or fully financed by the World Bank, including the national phone surveys in Burkina Faso, Ethiopia, Malawi, Mali, Nigeria, and Uganda that inform our research.

\section{Data Sharing}

The data are available from the World Bank's Microdata Library, High Frequency Phone Survey Catalog (https://microdata.worldbank.org/index.php/catalog/hfps) as well as LSMS catalog (https://microdata.worldbank.org/index.php/catalog/lsms).

\section{Transparency Statement}

The authors affirm that the manuscript is an honest, accurate, and transparent account of the study being reported; that no important aspects of the study have been omitted; and that any discrepancies from the study as planned have been explained.

\section{Dissemination to participants and related patient and public communities:}

Our research uses data from a large, anonymized sample of participants and there are thus no plans to disseminate the research to specific participants or patients beyond publishing it. 
medRxiv preprint doi: https://doi.org/10.1101/2021.06.28.21259320; this version posted July 2, 2021. The copyright holder for this preprint (which was not certified by peer review) is the author/funder, who has granted medRxiv a license to display the preprint in perpetuity. It is made available under a CC-BY-ND 4.0 International license .

\section{Licensing}

The Corresponding Author is aware that the World Bank external publishing department has recently agreed to grant to BMJ Publishing Group Limited a worldwide, non-exclusive license to publish an article produced by World Bank staff and consultants, and is committed to facilitate the conclusion of a similar agreement should this manuscript be accepted for publication.

\section{References}

1 Schellekens P, Indermit G. COVID-19 is a developing country pandemic. Future Development. 2021.https://www.brookings.edu/blog/future-development/2021/05/27/covid-19-is-a-developingcountry-pandemic/ (accessed 10 Jun 2021).

2 World Bank. Poverty and Shared Prosperity 2020 : Reversals of Fortune. Washington, DC: World Bank 2020. doi:10.1596/978-1-4648-1602-4

3 Rice BL, Annapragada A, Baker RE, et al. Variation in SARS-CoV-2 outbreaks across sub-Saharan Africa. Nat Med 2021;27:447-53. doi:10.1038/s41591-021-01234-8

4 Josephson A, Kilic T, Michler JD. Socioeconomic impacts of COVID-19 in low-income countries. Nat Hum Behav Published Online First: 30 March 2021. doi:10.1038/s41562-021-01096-7

5 Britton T, Ball F, Trapman P. A mathematical model reveals the influence of population heterogeneity on herd immunity to SARS-CoV-2. Science 2020;369:846-9.

doi: $10.1126 /$ science.abc6810

6 Aschwanden C. Five reasons why COVID herd immunity is probably impossible. Nature 2021;591:520-2. doi:10.1038/d41586-021-00728-2

7 Schellekens P. For greater vaccine equity, first fix these misconceptions. Future Development. 2021.https://www.brookings.edu/blog/future-development/2021/04/02/for-greater-vaccine-equityfirst-fix-these-misconceptions/ (accessed 10 Jun 2021).

8 Berkley S. COVAX explained. \#Vaccineswork. 2020.https://www.gavi.org/vaccineswork/covaxexplained (accessed 19 May 2021).

9 Wang W, Wu Q, Yang J, et al. Global, regional, and national estimates of target population sizes for covid-19 vaccination: descriptive study. BMJ 2020;:m4704. doi:10.1136/bmj.m4704

10 Yoo KJ, De Francisco Serpa N, Gordillo-Tobar A. Calculating Sub-Saharan Africa's COVID vaccination financing gap. Investing in Health. 2021.https://blogs.worldbank.org/health/calculatingsub-saharan-africas-covid-vaccination-financing-gap (accessed 19 May 2021).

11 World Bank. Population, total. World Development Indicators. 2019.https://data.worldbank.org/indicator/SP.POP.TOTL (accessed 15 Jun 2021).

$12 \mathrm{Fu} \mathrm{H}$, Sanchez-Paramo C. High-frequency monitoring of COVID-19 impacts. 2020.https://blogs.worldbank.org/opendata/high-frequency-monitoring-covid-19-impacts (accessed 27 Oct 2020). 
medRxiv preprint doi: https://doi.org/10.1101/2021.06.28.21259320; this version posted July 2, 2021. The copyright holder for this preprint (which was not certified by peer review) is the author/funder, who has granted medRxiv a license to display the preprint in perpetuity. It is made available under a CC-BY-ND 4.0 International license .

13 High-Frequency Phone Surveys. World Bank Microdata Library. https://microdata.worldbank.org/index.php/catalog/hfps (accessed 10 May 2021).

14 Ambel A, McGee K, Tsegay A. Reducing Bias in Phone Survey Samples. Effectiveness of Reweighting Techniques using Face-to-Face Surveys as Frames. Forthcoming.

15 Himelein K, Eckman S, Kastelic J, et al. High Frequency Mobile Phone Surveys of Households to Assess the Impacts of COVID-19. Guidelines on Sampling Design. Washington D.C.: : World Bank 2020. http://documents.worldbank.org/curated/en/742581588695955271/Guidelines-on-SamplingDesign

16 Josephson A, Kilic T, Michler JD. Socioeconomic Impacts of COVID-19 in Four African Countries. Washington D.C.: : The World Bank 2020.

17 Himelein K. Weight Calculations for Panel Surveys with Subsampling and Split-off Tracking. Statistics and Public Policy 2014;1:40-5. doi:10.1080/2330443X.2013.856170

18 Brubaker JM, Kilic T, Wollburg PR. Representativeness of Individual-Level Data in COVID-19 Phone Surveys: Findings from Sub-Saharan Africa. The World Bank 2021. https://econpapers.repec.org/paper/wbkwbrwps/9660.htm (accessed 19 May 2021).

19 Gentilini U, Almenfi M, Blomquist J, et al. Social Protection and Jobs Responses to COVID-19: A Real-Time Review of Country Measures (May 14, 2021). Washington D.C.: : World Bank 2021.

20 Stoop N, Hirvonen K, Maystadt J-F. Institutional mistrust and child vaccination coverage in Africa. BMJ Global Health 2021;6:e004595. doi:10.1136/bmjgh-2020-004595

21 Seydou A. Who wants COVID-19 vaccination? In 5 West African countries, hesitancy is high, trust low. Afrobarometer 2021. https://bit.ly/3hz1wZg

22 World Bank, UNDESA. Monitoring the State of Statistical Operations under the COVID-19 Pandemic : Highlights from the Third Round of a Global COVID-19 Survey of National Statistical Offices (NSOs). Washington, D.C.: : The World Bank 2020. http://documents.worldbank.org/curated/en/833751608029512958/Monitoring-the-State-ofStatistical-Operations-under-the-COVID-19-Pandemic-Highlights-from-the-Third-Round-of-aGlobal-COVID-19-Survey-of-National-Statistical-Offices-NSOs

23 World Bank, UNDESA. Monitoring the State of Statistical Operations under the COVID-19 Pandemic. Washington, D.C.: : World Bank 2020. https://documents.worldbank.org/en/publication/documentsreports/documentdetail/338481591648922978/monitoring-the-state-of-statistical-operations-underthe-covid-19-pandemic

24 World Bank, UNDESA. Monitoring the State of Statistical Operations under the COVID-19 Pandemic : Highlights from the Second Round of a Global COVID-19 Survey of National Statistical Offices (NSOs). Washington, D.C.: : World Bank 2020. https://documents1.worldbank.org/curated/en/297221597442670485/pdf/Monitoring-the-State-ofStatistical-Operations-under-the-COVID-19-Pandemic-Highlights-from-the-Second-Round-of-aGlobal-COVID-19-Survey-of-National-Statistical-Offices.pdf 
medRxiv preprint doi: https://doi.org/10.1101/2021.06.28.21259320; this version posted July 2, 2021. The copyright holder for this preprint (which was not certified by peer review) is the author/funder, who has granted medRxiv a license to display the preprint in perpetuity. It is made available under a CC-BY-ND 4.0 International license .

25 Barello S, Nania T, Dellafiore F, et al. 'Vaccine hesitancy' among university students in Italy during the COVID-19 pandemic. Eur J Epidemiol 2020;35:781-3. doi:10.1007/s10654-020-00670-z

26 Malik AA, McFadden SM, Elharake J, et al. Determinants of COVID-19 vaccine acceptance in the US. EClinicalMedicine 2020;26:100495. doi:10.1016/j.eclinm.2020.100495

27 Al-Mohaithef M, Padhi BK. Determinants of COVID-19 Vaccine Acceptance in Saudi Arabia: A Web-Based National Survey. JMDH 2020;Volume 13:1657-63. doi:10.2147/JMDH.S276771

28 Skjefte M, Ngirbabul M, Akeju O, et al. COVID-19 vaccine acceptance among pregnant women and mothers of young children: results of a survey in 16 countries. Eur J Epidemiol 2021;36:197-211. doi:10.1007/s10654-021-00728-6

29 Alqudeimat Y, Alenezi D, AlHajri B, et al. Acceptance of a COVID-19 Vaccine and its Related Determinants among the General Adult Population in Kuwait. Med Princ Pract Published Online First: 22 January 2021. doi:10.1159/000514636

30 Schwarzinger M, Watson V, Arwidson P, et al. COVID-19 vaccine hesitancy in a representative working-age population in France: a survey experiment based on vaccine characteristics. The Lancet Public Health 2021;6:e210-21. doi:10.1016/S2468-2667(21)00012-8

31 Benham B, JH Bloomberg School of Public Health. COVID-19 Vaccine Acceptance Falling Globally and in the U.S., Survey Finds. Johns Hopkins Bloomberg School of Public Health.

2021.https://www.jhsph.edu/news/news-releases/2021/covid-19-vaccine-acceptance-falling-globallyand-in-the-us-survey-finds.html (accessed 26 May 2021).

32 El-Elimat T, AbuAlSamen MM, Almomani BA, et al. Acceptance and attitudes toward COVID-19 vaccines: A cross-sectional study from Jordan. PLOS ONE 2021;16:e250555. doi:10.1371/journal.pone.0250555

33 Brenan M. Willingness to Get COVID-19 Vaccine Ticks Up to 63\% in U.S. Gallup. 2020.https://news.gallup.com/poll/327425/willingness-covid-vaccine-ticks.aspx (accessed $10 \mathrm{Jun}$ 2021).

34 Funk C, Tyson A. Intent to Get a COVID-19 Vaccine Rises to 60\% as Confidence in Research and Development Process Increases. Pew Research Center 2020.

35 Neumann-Böhme S, Varghese NE, Sabat I, et al. Once we have it, will we use it? A European survey on willingness to be vaccinated against COVID-19. The European Journal of Health Economics 2020;21:977-82. doi:10.1007/s10198-020-01208-6

36 Lazarus JV, Ratzan SC, Palayew A, et al. A global survey of potential acceptance of a COVID-19 vaccine. Nat Med 2021;27:225-8. doi:10.1038/s41591-020-1124-9

37 Sallam M. COVID-19 Vaccine Hesitancy Worldwide: A Concise Systematic Review of Vaccine Acceptance Rates. Vaccines 2021;9. doi:10.3390/vaccines9020160

38 Solís Arce JS, Warren SS, Meriggi NF, et al. COVID-19 Vaccine Acceptance and Hesitancy in Low and Middle Income Countries, and Implications for Messaging. Public and Global Health 2021. doi:10.1101/2021.03.11.21253419 
medRxiv preprint doi: https://doi.org/10.1101/2021.06.28.21259320; this version posted July 2, 2021. The copyright holder for this preprint

(which was not certified by peer review) is the author/funder, who has granted medRxiv a license to display the preprint in perpetuity.

It is made available under a CC-BY-ND 4.0 International license .

39 Africa CDC. COVID-19 Vaccine Perceptions: A 15 country study. 2021.

https://africacdc.org/download/covid-19-vaccine-perceptions-a-15-country-study/ (accessed 18 May 2021).

40 Kihara AB. Vaccination against COVID-19 in Africa. Int J Gynecol Obstet 2021;153:186-7. doi:10.1002/ijgo.13646

41 MacDonald NE. Vaccine hesitancy: Definition, scope and determinants. Vaccine 2015;33:4161-4. doi:https://doi.org/10.1016/j.vaccine.2015.04.036

\section{Appendix}

Table A.1. Household selection, number of households

\begin{tabular}{lcccccc} 
Panel A. Households $(N)$ & $\begin{array}{c}\text { Burkina } \\
\text { Faso }\end{array}$ & Ethiopia & Malawi & Mali & Nigeria & Uganda \\
\hline Pre-COVID-19 FtF survey & 7,010 & 6,770 & 3,181 & 7,000 & 4,976 & 3,098 \\
With phone numbers & 6,877 & 5,374 & 2,337 & 6,300 & 4,934 & 2,386 \\
Attempted to contact & 2,500 & 5,374 & 2,337 & 2,270 & 3,000 & 2,386 \\
Reached & 2,062 & 3,357 & 1,743 & 2,270 & 2,057 & 2,246 \\
Phone interviews completed & 1,945 & 2,701 & 1,589 & 1,765 & 1,766 & 2,129 \\
\hline
\end{tabular}

Table A.2. Willingness to get vaccinated by country and pooled, mean and 95\% confidence interval

If an approved vaccine to prevent coronavirus was available right now at no cost, would you agree to be vaccinated? - Yes

Burkina Faso, weighted Mean Ethiopia, weighted Malawi, weighted Mali, weighted Nigeria, weighted Uganda, weighted

Pooled, weighted $79.6 \%$ $97.9 \%$

$82.7 \%$

$64.5 \%$

$86.2 \%$ $84.5 \%$

$87.6 \%$

Pooled, unweighted

$82.4 \%$ Lower Bound Upper Bound N $77.0 \%$ $97.2 \%$ $80.0 \%$

$$
61.3 \%
$$
$83.9 \%$ $82.2 \%$

$86.4 \%$

$81.7 \%$

$\begin{array}{ll}82.3 \% & 1,945 \\ 98.6 \% & 2,701 \\ 85.4 \% & 1,589 \\ 67.8 \% & 1,765 \\ 88.5 \% & 1,766 \\ 86.8 \% & 2,129 \\ 88.8 \% & 11,895 \\ 83.1 \% & \end{array}$


Table A. 3. Unweighted descriptive statistics in the baseline F2F surveys and the HFPS.

\begin{tabular}{|c|c|c|c|c|c|c|c|c|c|c|c|c|}
\hline & \multicolumn{2}{|c|}{ Burkina Faso } & \multicolumn{2}{|c|}{ Ethiopia } & \multicolumn{2}{|c|}{ Malawi } & \multicolumn{2}{|c|}{ Mali } & \multicolumn{2}{|c|}{ Nigeria } & \multicolumn{2}{|c|}{ Uganda } \\
\hline & $\mathrm{F} 2 \mathrm{~F}$ & HFPS & $\mathrm{F} 2 \mathrm{~F}$ & HFPS & $\mathrm{F} 2 \mathrm{~F}$ & HFPS & $\mathrm{F} 2 \mathrm{~F}$ & HFPS & $\mathrm{F} 2 \mathrm{~F}$ & HFPS & $\mathrm{F} 2 \mathrm{~F}$ & HFPS \\
\hline Men & 45.5 & 78.7 & 47.3 & 62.7 & 47.6 & 59.8 & 47.4 & 78.9 & 48.3 & 72.3 & 48.2 & 50.7 \\
\hline HH heads & 28.7 & 86.1 & 38.5 & 82.5 & 37.0 & 74.5 & 27.1 & 82.3 & 32.7 & 79.3 & 35.1 & 74.5 \\
\hline Urban & 44.9 & 72.0 & 54.0 & 71.9 & 26.0 & 36.8 & 41.7 & 66.3 & 32.0 & 39.3 & 24.2 & 25.8 \\
\hline Primary education & 26.1 & 32.4 & 34.6 & 52.9 & 37.2 & 50.2 & 20.2 & 30.9 & 66.5 & 75.1 & 47.8 & 51.1 \\
\hline$<30$ years & 44.1 & 11.3 & 49.6 & 29.4 & 52.9 & 27.8 & 42.6 & 13.8 & 42.5 & 13.5 & 48.2 & 15.3 \\
\hline $30-60$ years & 45.7 & 72.2 & 42.1 & 62.4 & 38.2 & 62.7 & 45.7 & 70.4 & 44.9 & 69.0 & 40.0 & 66.2 \\
\hline $60+$ years & 10.1 & 16.5 & 8.3 & 8.3 & 8.9 & 9.5 & 11.7 & 15.9 & 12.6 & 17.5 & 11.8 & 18.6 \\
\hline Quintile 1 (poorest) & 18.7 & 14.0 & 11.4 & 4.6 & 15.7 & 8.7 & 18.2 & 14.6 & 12.7 & 9.5 & 18.2 & 15.8 \\
\hline Quintile 2 & 18.9 & 15.6 & 13.8 & 9.5 & 17.6 & 14.6 & 18.9 & 16.4 & 14.4 & 13.1 & 19.0 & 18.5 \\
\hline Quintile 3 & 19.9 & 17.9 & 15.0 & 12.4 & 17.4 & 16.1 & 21.0 & 19.0 & 19.2 & 18.7 & 20.4 & 20.7 \\
\hline Quintile 4 & 21.3 & 22.5 & 20.3 & 22.0 & 22.2 & 23.5 & 20.7 & 22.2 & 21.4 & 21.9 & 21.7 & 22.5 \\
\hline Quintile 5 (richest) & 21.2 & 30.0 & 39.4 & 51.5 & 27.1 & 37.1 & 21.2 & 27.8 & 32.3 & 36.9 & 20.7 & 22.5 \\
\hline Observations & 24,396 & 1,742 & 17,563 & 2,701 & 8,588 & 1,589 & 24,394 & 1,765 & 15,230 & 1,766 & 8,763 & 2,129 \\
\hline
\end{tabular}

Note: The table shows descriptive statistics and sample sizes for the face-to-face (F2F) pre-Covid samples of the general adult population ( $>15$ years) and the highfrequency phone surveys (HFPS) during the pandemic. All values except observation numbers in percent. 
Table A.4. Estimated acceptance rates using household or individual weights.

\begin{tabular}{|c|c|c|c|c|c|c|c|c|c|c|c|c|}
\hline & \multicolumn{2}{|c|}{ Burkina Faso } & \multicolumn{2}{|c|}{ Ethiopia } & \multicolumn{2}{|c|}{ Malawi } & \multicolumn{2}{|c|}{ Mali } & \multicolumn{2}{|c|}{ Nigeria } & \multicolumn{2}{|c|}{ Uganda } \\
\hline & $\mathrm{HH}$ & Indiv. & $\mathrm{HH}$ & Indiv. & $\mathrm{HH}$ & Indiv. & $\mathrm{HH}$ & Indiv. & $\mathrm{HH}$ & Indiv. & $\mathrm{HH}$ & Indiv. \\
\hline \multirow[t]{2}{*}{ Overall } & 0.798 & 0.815 & 0.979 & 0.973 & 0.827 & 0.828 & ב0.645 & (0.657 & 0.862 & "0.843 & 0.845 & 0.844 \\
\hline & $(0.0135)$ & $(0.0176)$ & $(0.0036)$ & $(0.0068)$ & $(0.0137)$ & $(0.0176)$ & $(0.0166)$ & $(0.0241)$ & $(0.0118)$ & $(0.0168)$ & $(0.0116)$ & $(0.0129)$ \\
\hline \multirow[t]{2}{*}{ Men } & 0.800 & 0.839 & 0.987 & 0.987 & 0.846 & 0.843 & 0.642 & 0.666 & 0.901 & 0.888 & 0.854 & 0.862 \\
\hline & $(0.0151)$ & $(0.0178)$ & $(0.0037)$ & $(0.0050)$ & $(0.0162)$ & $(0.0216)$ & $(0.0185)$ & $(0.0281)$ & $(0.0126)$ & $(0.0200)$ & $(0.0160)$ & $(0.0161)$ \\
\hline \multirow[t]{2}{*}{ Women } & 0.788 & 0.779 & 0.958 & 0.949 & 0.798 & 0.816 & 0.657 & 0.643 & 0.757 & 0.793 & 0.835 & 0.831 \\
\hline & $(0.0304)$ & $(0.0346)$ & $(0.0088)$ & $(0.0164)$ & $(0.0240)$ & $(0.0268)$ & $(0.0374)$ & $(0.0435)$ & $(0.0269)$ & $(0.0282)$ & $(0.0169)$ & $(0.0191)$ \\
\hline \multirow[t]{2}{*}{ Urban } & 0.653 & 0.695 & 0.954 & 0.947 & 0.700 & 0.719 & 0.669 & 0.668 & 0.820 & 0.814 & 0.810 & 0.802 \\
\hline & $(0.0207)$ & $(0.0298)$ & $(0.0070)$ & $(0.0131)$ & $(0.0318)$ & $(0.0398)$ & $(0.0156)$ & $(0.0324)$ & $(0.0229)$ & $(0.0302)$ & $(0.0232)$ & $(0.0260)$ \\
\hline \multirow[t]{2}{*}{ Rural } & 0.891 & 0.905 & 0.991 & 0.986 & 0.859 & 0.859 & 0.635 & 0.650 & 0.881 & 0.858 & 0.861 & 0.862 \\
\hline & $(0.0160)$ & $(0.0181)$ & $(0.0040)$ & $(0.0078)$ & $(0.0148)$ & $(0.0193)$ & $(0.0227)$ & $(0.0335)$ & $(0.0135)$ & $(0.0203)$ & $(0.0132)$ & $(0.0147)$ \\
\hline \multirow[t]{2}{*}{ Q1 } & 0.914 & 0.928 & 0.997 & 0.997 & 0.903 & 0.922 & 0.640 & 0.643 & 0.949 & 0.957 & 0.941 & 0.956 \\
\hline & $(0.0237)$ & $(0.0226)$ & $(0.0023)$ & $(0.0020)$ & $(0.0335)$ & $(0.0280)$ & $(0.0382)$ & $(0.0572)$ & $(0.0244)$ & $(0.0250)$ & $(0.0163)$ & $(0.0120)$ \\
\hline \multirow[t]{2}{*}{ Q2 } & 0.914 & 0.923 & 0.997 & 0.994 & 0.923 & 0.906 & 0.703 & 0.690 & 0.884 & 0.849 & 0.905 & 0.863 \\
\hline & $(0.0224)$ & $(0.0309)$ & $(0.0029)$ & $(0.0055)$ & $(0.0183)$ & $(0.0284)$ & $(0.0347)$ & $(0.0582)$ & $(0.0340)$ & $(0.0493)$ & $(0.0202)$ & $(0.0321)$ \\
\hline \multirow[t]{2}{*}{ Q3 } & 0.823 & 0.812 & 0.971 & 0.958 & 0.819 & 0.775 & 0.702 & 0.699 & 0.911 & 0.851 & 0.849 & 0.856 \\
\hline & $(0.0312)$ & $(0.0406)$ & $(0.0136)$ & $(0.0249)$ & $(0.0329)$ & $(0.0549)$ & $(0.0348)$ & $(0.0552)$ & $(0.0196)$ & $(0.0416)$ & $(0.0263)$ & $(0.0263)$ \\
\hline \multirow[t]{2}{*}{ Q4 } & 0.800 & 0.766 & 0.986 & 0.984 & 0.745 & 0.779 & 0.602 & 0.664 & 0.834 & 0.840 & 0.785 & 0.784 \\
\hline & $(0.0304)$ & $(0.0466)$ & $(0.0048)$ & $(0.0052)$ & $(0.0356)$ & $(0.0400)$ & $(0.0392)$ & $(0.0478)$ & $(0.0286)$ & $(0.0334)$ & $(0.0294)$ & $(0.0324)$ \\
\hline \multirow[t]{2}{*}{ Q5 } & 0.548 & 0.606 & 0.957 & 0.949 & 0.797 & 0.819 & 0.582 & 0.594 & 0.809 & 0.798 & 0.799 & 0.796 \\
\hline & $(0.0312)$ & $(0.0477)$ & $(0.0082)$ & $(0.0171)$ & $(0.0256)$ & $(0.0282)$ & $(0.0361)$ & $(0.0484)$ & $(0.0218)$ & $(0.0304)$ & $(0.0249)$ & $(0.0282)$ \\
\hline
\end{tabular}

Note: The table compares estimated acceptance rates for a free, approved covid-19 vaccine for different demographics. It distinguishes between using weights that correct for coverage and non-response bias at the household-level (household weights) and, where available, using individual-level phone weights that also correct for respondent selection at the individual-level (individual weights). The samples do not comprise observations for which no individual weight could be calibrated due to missing baseline information. Standard errors in parentheses. 
Table A.5. Logistic regression on the correlates of hesitancy using individual-level survey weights, marginal effects.

\begin{tabular}{|c|c|c|c|c|c|c|}
\hline VARIABLES & $\begin{array}{c}(1) \\
\text { Burkina } \\
\text { Faso } \\
\end{array}$ & $\begin{array}{c}\text { (2) } \\
\text { Ethiopia }\end{array}$ & $\begin{array}{c}\text { (3) } \\
\text { Malawi } \\
\end{array}$ & $\begin{array}{c}\text { (4) } \\
\text { Mali } \\
\end{array}$ & $\begin{array}{c}(5) \\
\text { Nigeria } \\
\end{array}$ & $\begin{array}{c}\text { (6) } \\
\text { Uganda }\end{array}$ \\
\hline Respondent is male & $\begin{array}{c}0.0265 \\
(0.0351)\end{array}$ & $\begin{array}{c}0.0125 \\
(0.00942)\end{array}$ & $\begin{array}{c}0.0272 \\
(0.0371)\end{array}$ & $\begin{array}{l}0.116^{* *} \\
(0.0494)\end{array}$ & $\begin{array}{c}0.0307 \\
(0.0406)\end{array}$ & $\begin{array}{l}0.00464 \\
(0.0244)\end{array}$ \\
\hline Lives in urban area & $\begin{array}{c}-0.0750 * * \\
(0.0323)\end{array}$ & $\begin{array}{c}-0.0236^{* *} \\
(0.0116)\end{array}$ & $\begin{array}{c}-0.0930 * * * \\
(0.0348)\end{array}$ & $\begin{array}{l}-0.0221 \\
(0.0388)\end{array}$ & $\begin{array}{l}-0.00481 \\
(0.0370)\end{array}$ & $\begin{array}{l}0.00853 \\
(0.0223)\end{array}$ \\
\hline Years of education & $\begin{array}{l}-0.00462 \\
(0.00293)\end{array}$ & $\begin{array}{c}-0.00154 \\
(0.000938)\end{array}$ & $\begin{array}{c}-0.0123 * * * \\
(0.00417)\end{array}$ & $\begin{array}{l}-0.00337 \\
(0.00356)\end{array}$ & $\begin{array}{l}-0.00657 \\
(0.00410)\end{array}$ & $\begin{array}{l}-0.00261 \\
(0.00247)\end{array}$ \\
\hline Age group, 30-60 yrs & $\begin{array}{c}0.0354 \\
(0.0490)\end{array}$ & $\begin{array}{l}-0.00114 \\
(0.00984)\end{array}$ & $\begin{array}{l}-0.00707 \\
(0.0387)\end{array}$ & $\begin{array}{l}-0.0117 \\
(0.0476)\end{array}$ & $\begin{array}{l}-0.0124 \\
(0.0356)\end{array}$ & $\begin{array}{l}-0.0340 \\
(0.0294)\end{array}$ \\
\hline Age group, $60+$ yrs & $\begin{array}{l}0.124 * * \\
(0.0491)\end{array}$ & $\begin{array}{l}0.00134 \\
(0.0196)\end{array}$ & $\begin{array}{l}-0.0331 \\
(0.0720)\end{array}$ & $\begin{array}{l}-0.0471 \\
(0.0612)\end{array}$ & $\begin{array}{l}-0.0321 \\
(0.0628)\end{array}$ & $\begin{array}{c}0.0134 \\
(0.0317)\end{array}$ \\
\hline Household head & $\begin{array}{c}-0.00843 \\
(0.0401)\end{array}$ & $\begin{array}{l}0.0226^{*} \\
(0.0119)\end{array}$ & $\begin{array}{c}-0.00400 \\
(0.0385)\end{array}$ & $\begin{array}{c}-0.0972 * \\
(0.0549)\end{array}$ & $\begin{array}{c}0.0333 \\
(0.0415)\end{array}$ & $\begin{array}{c}0.0204 \\
(0.0267)\end{array}$ \\
\hline Household Size & $\begin{array}{c}0.00287 \\
(0.00510)\end{array}$ & $\begin{array}{c}0.00186 \\
(0.00181)\end{array}$ & $\begin{array}{c}0.00971 \\
(0.00842)\end{array}$ & $\begin{array}{c}-0.00534^{*} \\
(0.00322)\end{array}$ & $\begin{array}{c}0.00834 \\
(0.00591)\end{array}$ & $\begin{array}{c}0.00268 \\
(0.00564)\end{array}$ \\
\hline Expenditure, 2nd quintile & $\begin{array}{l}0.00107 \\
(0.0502)\end{array}$ & $\begin{array}{l}0.00591 \\
(0.0131)\end{array}$ & $\begin{array}{l}-0.0203 \\
(0.0469)\end{array}$ & $\begin{array}{c}0.0270 \\
(0.0638)\end{array}$ & $\begin{array}{l}-0.0994 \\
(0.0757)\end{array}$ & $\begin{array}{c}-0.0871 * * * * \\
(0.0323)\end{array}$ \\
\hline Expenditure, 3rd quintile & $\begin{array}{l}-0.0660 \\
(0.0428)\end{array}$ & $\begin{array}{l}-0.0277 \\
(0.0193)\end{array}$ & $\begin{array}{l}-0.178 * * \\
(0.0712)\end{array}$ & $\begin{array}{c}0.0325 \\
(0.0537)\end{array}$ & $\begin{array}{l}-0.0371 \\
(0.0666)\end{array}$ & $\begin{array}{c}-0.0813 * * * \\
(0.0287)\end{array}$ \\
\hline Expenditure, 4th quintile & $\begin{array}{c}-0.0921^{* *} \\
(0.0466)\end{array}$ & $\begin{array}{r}-0.00480 \\
(0.0118)\end{array}$ & $\begin{array}{l}-0.118 * * \\
(0.0522)\end{array}$ & $\begin{array}{l}-0.0504 \\
(0.0595)\end{array}$ & $\begin{array}{l}-0.0428 \\
(0.0588)\end{array}$ & $\begin{array}{c}-0.122 * * * \\
(0.0316)\end{array}$ \\
\hline Expenditure, 5th (richest) quintile & $\begin{array}{c}-0.123 * * \\
(0.0528)\end{array}$ & $\begin{array}{c}-0.0157 \\
(0.0126)\end{array}$ & $\begin{array}{c}-0.0143 \\
(0.0461)\end{array}$ & $\begin{array}{l}-0.115^{*} \\
(0.0684)\end{array}$ & $\begin{array}{l}-0.0679 \\
(0.0631)\end{array}$ & $\begin{array}{c}-0.103 * * * \\
(0.0317)\end{array}$ \\
\hline Willing to be tested for covid-19 & $\begin{array}{c}0.271 * * * \\
(0.0287)\end{array}$ & $\begin{array}{c}0.0839 * * * \\
(0.0149)\end{array}$ & $\begin{array}{c}0.249 * * * \\
(0.0440)\end{array}$ & $\begin{array}{c}0.468 * * * \\
(0.0171)\end{array}$ & $\begin{array}{c}0.224 * * * \\
(0.0302)\end{array}$ & $\begin{array}{c}0.348 * * * \\
(0.0287)\end{array}$ \\
\hline HH received assistance during covid-19 & $\begin{array}{c}0.0840 * \\
(0.0505)\end{array}$ & $\begin{array}{c}0.0177 \\
(0.0127)\end{array}$ & $\begin{array}{l}-0.0412 \\
(0.0455)\end{array}$ & $\begin{array}{c}0.0406 \\
(0.0598)\end{array}$ & $\begin{array}{c}-0.00112 \\
(0.0328)\end{array}$ & $\begin{array}{c}0.0597 * * * \\
(0.0214)\end{array}$ \\
\hline Gov't not trustworthy & & & $\begin{array}{l}-0.0408 \\
(0.0322)\end{array}$ & & & \\
\hline Satisfied with gov't response & & & & $\begin{array}{c}0.0356 \\
(0.0446)\end{array}$ & $\begin{array}{c}0.0235 \\
(0.0325)\end{array}$ & \\
\hline Observations & 1,738 & 2,654 & 1,542 & 1,590 & 1,700 & 2,106 \\
\hline Pseudo R2 & 0.225 & 0.357 & 0.136 & 0.325 & 0.162 & 0.238 \\
\hline
\end{tabular}

Robust standard errors in parentheses. $* * * \mathrm{p}<0.01, * * \mathrm{p}<0.05, * \mathrm{p}<0.1$. Weighted logit regressions with willingness to take a free, approved covid-19 vaccine as dependent variable. 
medRxiv preprint doi: https://doi.org/10.1101/2021.06.28.21259320; this version posted July 2, 2021. The copyright holder for this preprint (which was not certified by peer review) is the author/funder, who has granted medRxiv a license to display the preprint in perpetuity.

It is made available under a CC-BY-ND 4.0 International license .

Table A.6: Bivariate logistic regression on government trust and satisfaction using householdlevel survey weights.

VARIABLES

Government not trustworthy

Satisfied with government

response

Observations

Controls

Pseudo R2

Robust standard errors in parentheses. $* * * \mathrm{p}<0.01, * * \mathrm{p}<0.05$,
(1)

(3)

Nigeria

$-0.0638 * *$

$(0.0322)$

$0.161 * * * \quad 0.0568 * *$

(0.0552) (0.0232)

$1,631 \quad 1,766$

YES YES

$\mathrm{p}<0.1$ 